\title{
Estimation of Phenotypic Diversity in Field Populations of Magnaporthe grisea From Two Upland Rice Cultivars
}

\author{
Gisele B. Silva ${ }^{1,2}$, Laércio Zambolim², Anne S. Prabhu², Leila G. Araújo² \& Francisco J.P. Zimmermann ${ }^{3}$ \\ ${ }^{1}$ Universidade Federal Rural da Amazônia, ICA, CEP 66077-530, Belém, PA, e-mail: gisele.barata@ufra.edu.br; \\ ${ }^{2}$ Universidade Federal de Viçosa, Departamento de Fitopatologia, CEP 36570-000, Viçosa, MG; \\ ${ }^{3}$ Embrapa Arroz e Feijão, Cx. Postal 179, CEP 75375-000, Santo Antônio de Goiás, GO
}

Author for correspondence: Gisele Barata da Silva

SILVA, G.B., ZAMBOLIM, L., PRABHU, A.S., ARAUJO, L.G. \& ZIMMERMANN, F.J.P. Estimation of phenotypic diversity in field populations of Magnaporthe grisea from two upland rice cultivars. Fitopatologia Brasileira 32:005-012. 2007.

\begin{abstract}
The phenotypic diversity of Magnaporthe grisea was evaluated based on leaf samples with blast lesions collected from eight commercial fields of the upland rice cultivars 'BRS Primavera' and 'BRS Bonança', during the growing seasons of 2001/2002 and 2002/2003, in Goias State. The number of $M$. grisea isolates from each field utilized for virulence testing varied from 28 to 47. Three different indices were used based on reaction type in the eight standard international differentials and eight Brazilian differentials. The M. grisea subpopulations of 'Primavera' and 'Bonança', as measured by Simpson, Shannon and Gleason indices, showed similar phenotypic diversities. The Simpson index was more sensitive relation than those of Shannon and Gleason for pathotype number and standard deviation utilizing Brazilian differentials. However, the Gleason index was sensitive to standard deviation for international differentials. The sample size did not significantly influence the diversity index. The two sets of differential cultivars used in this study distinguished phenotypic diversity in different ways in all of the eight subpopulations analyzed. The phenotypic diversity determined based on eight differential Brazilian cultivars was lower in commercial rice fields of 'Primavera' than in the fields of 'Bonança,' independent of the diversity index utilized, year and location. Considering the Brazilian differentials, the four subpopulations of 'BRS Primavera' did not show evenness in distribution and only one pathotype dominated in the populations. The even distribution of pathotype was observed in three subpopulations of 'BRS Bonança'. The pathotype diversity of $M$. grisea was determined with more precision using Brazilian differentials and Simpson index.
\end{abstract}

Additional keywords: Oryza sativa, Pyricularia grisea, population dynamics, rice blast, pathotypes, virulence.

\section{RESUMO}

Estimativa de diversidade fenotípica nas populações de Magnaporhe grisea de duas cultivares de arroz de terras altas

A diversidade fenotípica de Magnaporthe grisea foi avaliada baseada em amostras de folhas com brusone coletadas de oito lavouras de arroz, 'Primavera' e 'Bonança', durante os anos de 2001/2002 e 2002/2003, no Estado de Goiás. O número de isolados de $M$. grisea, em cada lavoura, utilizado para teste de virulência variou de 28 a 47 . Foram utilizados três diferentes índices baseados no tipo de reação em oito diferenciadoras internacionais e oito diferenciadoras brasileiras. A diversidade fenotípica das subpopulações de M. grisea de 'Primavera' e 'Bonança' foi semelhante pelos índices de Shannon, Simpson e Gleason. O índice de Simpson foi mais sensível do que Shannon e Gleason quanto ao número de patótipo e desvio padrão da freqüência utilizando diferenciadoras brasileiras. Entretanto, o índice de Gleason foi melhor quanto ao número de patótipos e desvio padrão da freqüência, considerando as diferenciadoras internacionais. O tamanho da amostra não influenciou significativamente os índices de diversidade. Os dois conjuntos de diferenciadoras utilizados nesse estudo evidenciaram diversidade fenotípica de diferentes maneiras em todas as oito subpopulações analisadas. A diversidade fenotípica, determinada pelas diferenciadoras brasileiras foi menor nas lavouras de 'Primavera' do que em 'Bonança', independente do índice, ano e local. Considerando as diferenciadoras brasileiras, as quatro subpopulações de 'Primavera' não mostraram distribuição uniforme, predominando apenas um patótipo nas subpopulações. A distribuição uniforme de patótipos foi observada em três subpopulações de 'Bonança'. A diversidade de patótipos de M. grisea foi determinada com maior precisão combinando as diferenciadoras brasileiras e o índice de Simpson.

Palavras-chave adicionais: Oryza sativa, Pyricularia grisea, dinâmica de população, brusone, patótipos, virulência.

\section{INTRODUCTION}

The widely grown cultivars Primavera and Bonança are susceptible to rice blast disease, caused by Magnaporthe grisea (Hebert) Barr [= Pyricularia grisea (Cooke) Sacc.] and

\footnotetext{
*Part of the Ph.D. thesis submitted by the first author to the Federal University of Viçosa. Viçosa, MG. 2004.
}

the annual yield losses caused by this disease are of major concern to upland rice growers. The mean grain yield losses due to rice blast in the four widely grown upland rice cultivars ('Bonança', 'Primavera', 'Carajás' and 'Caiapó') were estimated to be $56.9 \%$ under experimental field conditions (Prabhu et al., 2002a). Considering the mean panicle blast severity of $75 \%$ for 'Primavera' and 46\% for 'Bonança', the losses in empty spikelets were $42 \%$ and $11 \%$, respectively (Araújo et al., 2004). 
Cultivar specificity of isolates and variability within pathogen population are major factors in adopting appropriate breeding strategies. Earlier studies in different parts of the world were focused on phenotypic variability in M. grisea (Ou, 1980). Virulence and phenotypic diversity are commonly determined based on the identification of pathogenic races or pathotypes affecting diverse genotypes in breeders' plots. Virulence in the field also preexists in low frequencies for resistance genes, which have not so far been utilized in the resistance breeding of rice cultivars (Prabhu et al., 2002b). The detection of rare pathotypes has great value in predicting the effectiveness of the resistance genes in newly released cultivars. In an earlier investigation, the international races IB-1, IB-9 and IB-41 were found to be predominant among 85 isolates retrieved from 14 upland rice cultivars. A set of eight commercial Brazilian rice cultivars was utilized as additional differentials for describing the pathotype diversity of $M$. grisea. Isolates virulent and avirulent to 'Primavera' were found within the pathotype IB-1 utilizing Brazilian differentials (Prabhu et al., 2002b). In another study, it has been shown that 46 isolates of $M$. grisea, collected from 'Primavera' during 1997-2001, belonged to 11 international and 15 Brazilian pathotypes (Prabhu et al., 2003). Of 12 monosporic isolates collected from two leaf lesions of 'Primavera' in two urban areas of Lagomar and Uberlandia, in Minas Gerais State, four races IA-1, 1C-9, IB-1 and IC-65 were identified (Cornelio, 2001). International races representing the majority of the race groups were earlier reported from the upland rice growing States (Malavolta \& Souza, 1992; Filippi \& Prabhu, 2001; Prabhu \& Filippi, 2001; Prabhu et al., 2002b). Pathogenic diversity is generally very high in experimental fields and at cultivar breeding sites where the conditions are highly favorable for disease development (Correa-Victoria \& Zeigler, 1993; Zeigler et al., 1995; Filippi \& Prabhu, 2001). Levy et al. (1993) identified 39 races in one collection of 151 isolates retrieved from 15 rice cultivars in Colômbia. Chen et al. (1995) analyzed the population structure of M. grisea at two screening sites in the Philippines and concluded that host selection appeared to play a major role in structuring the pathogen population.

Thus, the estimation of relative prevalence and geographic distribution of races is more important in the isolates collected from commercial rice cultivars (Leonard et al., 1992, Filippi et al.,
2002, Prabhu et al., 2002c). The analysis of 470 isolates collected from eight cultivars from 18 farmers' fields in Arkansas State in the U.S.A, showed predominance of races IB-49 and IC-17, due to high selection pressure exerted by the cultivars (Xia et al., 2000). These studies showed that the level of phenotypic diversity in commercial rice farms is an important parameter to characterize different pathogen populations of M. grisea. It is not known how far the widely grown upland rice cultivars Primavera and Bonança influenced the evolution of population structure.

Phenotypic diversity refers to a rate of temporal and spatial change. A pathogen population is considered more diverse if it consists of a large number of phenotypes for a given number of isolates. It is characterized by even distribution of phenotypes in which case a small number of phenotypes dominate, and when differences between phenotypes in genetic and other virulence attributes are large (Groth\& Roelfs, 1987; Kosman, 1996). Shannon and Simpson indexes based on relative frequency of different races are widely used to characterize the pathogen population. The ratio of phenotypes (races) to isolates sampled depends upon the sample size, and a larger sample size is required to detect rare phenotypes. Gleason index is considered less sensitive to the sample size, because the increase in sample size is correspondingly diminished in its logarithmic form and simple to calculate (Groth \& Roelfs, 1987). Some isolates of $M$. grisea exhibit distinct differences in virulence pattern while others are similar depending upon the set of differentials utilized. So far, no attempt has been made to determine spatial distribution of virulent pathotypes in the commercial rice fields of 'Primavera' and 'Bonança'.

The objectives of the present study were to estimate the phenotypic diversity between field populations of $M$. grisea from the rice cultivars 'Primavera' and 'Bonança' and examine the utility of fixed sets of Brazilian local differentials and international standard race differentials to describe different aspects of diversity indexes.

\section{MATERIALS AND METHODS}

Isolates of $M$. grisea were collected from eight commercial fields of the cultivars 'Primavera' and 'Bonança' (Table 1), in the State of Goias, during the consecutive rice growing seasons of 2001-2003. The fields selected were

TABLE 1 - Number of Magnaporthe grisea isolates collected in farmers' fields and utilized in the analysis of virulence in the Goias state

\begin{tabular}{|c|c|c|c|c|c|}
\hline \multirow[t]{2}{*}{ Cultivar $^{1}$} & \multirow[t]{2}{*}{ Location } & \multirow[t]{2}{*}{ Year } & \multirow[t]{2}{*}{ Field size (ha) } & \multicolumn{2}{|c|}{ Number of isolates } \\
\hline & & & & Collected & Tested \\
\hline Bonança (B1)* & Piracanjuba & $2001 / 2002$ & 150 & 148 & 34 \\
\hline Bonança (B2) & Piracanjuba & $2001 / 2002$ & 83 & 236 & 29 \\
\hline Bonança (B3) & Bela Vista & $2002 / 2003$ & 88 & 50 & 45 \\
\hline Bonança (B4) & Uruana & $2002 / 2003$ & 8 & 50 & 28 \\
\hline Primavera $(\mathrm{P} 1)$ & St. Antonio de Goiás & $2001 / 2002$ & 2 & 312 & 47 \\
\hline Primavera (P2) & St. Antonio de Goiás & $2001 / 2002$ & 9 & 221 & 44 \\
\hline Primavera (P3) & Ceres & $2002 / 2003$ & 288 & 50 & 47 \\
\hline Primavera $(\mathrm{P} 4)$ & Bela Vista & $2002 / 2003$ & 137 & 50 & 32 \\
\hline
\end{tabular}

*Designation of the field. 
isolated and no other cultivar was planted within a minimum distance of approximately $5.0 \mathrm{~km}$. Regular inspections of the fields were made for the presence of leaf blast. Leaf samples with sporulating lesions were collected, at the vegetative phase of crop growth, varying from 30 to 50 days after planting. Collection procedure consisted of selecting a representative area of about one hectare of the rice crop, and pre-marking it with five wooden poles, four at each corner and one in the center of the selected sampling area at approximately $100 \mathrm{~m}$ distance. Fifty or more leaves showing a minimum of one sporulating susceptible lesion type were collected around each one of the marked sites of each field. In most of the cases, the isolates were established from one conidium per lesion and from two to three lesions per leaf. For evaluation, isolates varying from 28 to 47 per field were randomly selected according to cultivar, location and year of collection (Table 1).

The virulence frequency of the selected isolates was tested under controlled greenhouse conditions, utilizing 16 genotypes including eight standard international differentials ('Dular', 'Kanto 51', 'NP125', 'Raminad Str 3', 'Usen', 'Zenith', 'Caloro' and 'Sha-tiao-tsao') and eight Brazilian local differentials ('Carajás', 'Confiança', 'Maravilha', 'Primavera', 'Progresso', 'Caiapó', 'IAC-47', 'IAC-201'). These differentials were sown in plastic trays $(15 \times 30 \times 10$ $\mathrm{cm})$ containing $3 \mathrm{~kg}$ of soil fertilized with NPK (5g of 5$30-15+\mathrm{Zn}$ and $3 \mathrm{~g}$ of ammonium sulfate per $3 \mathrm{~kg}$ of soil). Sixteen cultivars per tray were sown ( 10 to 12 seeds/cultivar) in $5 \mathrm{~cm}$ rows.

Spore production and inoculation procedures were carried out as described in earlier investigation (Filippi et al. 1999). Twenty-day-old plants were inoculated by spraying the aqueous spore suspension $\left(3.10^{5}\right.$ conidia per $\left.\mathrm{mL}\right)$ on leaves, until run-off, using an atomizer connected to an air compressor. The physiologic races were identified based on the reaction of eight standard international differentials (Atkins et al., 1967; Ling \& Ou, 1969). Leaf blast reaction was assessed seven to nine days after inoculation taking into consideration only two types of host reaction, compatible or susceptible and incompatible or resistant reaction. The infection types 0 to 3 were considered as resistant and 4 to 9 as susceptible in the disease evaluation scale of $0-9$ (International Rice Research Institute, 1988). In the event of ambiguous or intermediate reaction, inoculation tests were repeated whenever necessary and the ones that gave consistent and uniform reaction were utilized for analysis. A tray containing international and Brazilian differential cultivars as non-inoculated control was maintained to ensure that no contamination occurred during the inoculation procedure.

The same key utilized for identifying international races (Ling \& Ou, 1969) was used for designating Brazilian races (Prabhu et al. 2002b). The Brazilian races were prefixed by the letter "B" instead of the "I" of the international races, and the numbers following the group letters indicate the pathotype number.

\section{Analysis}

Each pathotype was considered as a distinct phenotype for measuring phenotypic diversity between populations. Shannon, Simpson and Gleason indices were calculated for each one of the eight fields of rice 'Primavera' and 'Bonança'.

Shannonindex(Goodwin, 1997)was used to determine the similarities of the frequencies of the different pathotypes in a set of isolates (Set $1=$ international differentials and Set 2 = Brazilian differentials) by the following formula:

$\mathrm{H}_{\mathrm{SH}}=-\sum\left(\mathrm{P}_{\mathrm{j}} \ln \mathrm{P}_{\mathrm{j}}\right)$. Where $\mathrm{j}=1 \ldots \mathrm{n}$, and $\mathrm{p}_{\mathrm{j}}$ is the frequency of $i$ th $j$ th pathotype in the set of isolates.

Simpson index (Pielou, 1975) of diversity was another popular diversity index advocated by Groth \& Roelfs (1987) for plant pathogens to determine the number of phenotypes and evenness of their distribution. It was calculated by the following formula:

$\mathrm{H}_{\mathrm{S}}=1-\sum\left[n_{i}\left(n_{i}-1\right) / \mathrm{N}(\mathrm{N}-1)\right]$. Where $n_{i}$ is the number of isolates of the $i$ th phenotype and $\mathrm{N}$ is the sample size.

Gleason index (Groth \& Roelfs, 1987) was used to detect the number of distinct pathotypes present indicating the richness aspect of diversity and calculated by the following formula:

$\mathrm{H}_{\mathrm{G}}=(\mathrm{n}-1) / \ln (\mathrm{N})$. Where $\mathrm{n}$ is the number of pathotypes and $\mathrm{N}$ is the number of isolates in the sample population.

\section{RESULTS AND DISCUSSION}

Sixty-one Brazilian pathotypes were identified in 306 isolates collected from eight rice fields of 'Bonança' and 'Primavera', during two rice growing seasons. They represented the groups $\mathrm{BA}, \mathrm{BB}, \mathrm{BC}, \mathrm{BD}, \mathrm{BE}, \mathrm{BF}, \mathrm{BG}, \mathrm{BH}$ and $\mathrm{BI}$ with group $\mathrm{BB}$ being predominant. The pathotypes in order of their prevalence, independent of the rice cultivar and year of collection, were BD-16, BB-21, BB-9, BB-29 and $\mathrm{BC}-14$ (Table 2). One hundred and thirty one isolates of M. grisea collected from four fields of 'BRS Primavera' belonged to the pathotype BD-16, indicating high cultivar specificity to the isolates. The Brazilian differentials 'Confiança', 'Maravilha' and 'Primavera' were susceptible, whereas 'Carajás', 'Progresso', 'Caiapó', 'IAC-47' and 'IAC-21' were resistant to pathotype BD-16. Similar results were obtained in a previous study with isolates collected from experimental fields during a 3-year period, where five of the four isolates were pathotype BD-16 (Prabhu et al., 2002b). The pathotype BB-21 was identified in 25 of 45 isolates collected from one field of 'BRS Bonança' in Bela Vista in the rice growing season of 2002/03 (Table 2). In an earlier investigation, all of the six isolates collected from 'Bonança' were identified as pathotype BB-21 (Prabhu et al., 2002b). It is interesting to note that in three fields of 'Bonança' the number of pathotype ranged from 14 to 21, indicating high pathotypic diversity. Rare pathotypes do exist under natural field conditions in both cultivars and, possibly, shifts in pathogen population can occur over time as there is directional selection in favor of the virulence present in those pathotypes. 
G.B. Silva et al.

TABLE 2 - Brazilian pathotypes and their frequency in eight different upland rice fields

\begin{tabular}{|c|c|c|c|c|c|c|c|c|c|c|}
\hline \multirow[b]{2}{*}{ Pathotype $^{1}$} & \multicolumn{4}{|c|}{ Rice filed $^{2}$} & \multicolumn{2}{|l|}{ Total } & \multicolumn{3}{|c|}{ R ice filed ${ }^{3}$} & \multirow{2}{*}{$\begin{array}{c}\text { Total } \\
\text { number } \\
\text { of isolates } 4\end{array}$} \\
\hline & $\begin{array}{c}\text { B1 } \\
(n=34)\end{array}$ & $\begin{array}{c}\text { B2 } \\
(n=29)\end{array}$ & $\begin{array}{c}\text { B3 } \\
(n=45)\end{array}$ & $\begin{array}{r}B 4^{5} \\
(n=28)\end{array}$ & $\begin{array}{c}\text { number of } \\
\text { isolates } 4\end{array}$ & $\begin{array}{c}P 1 \\
(n=44)\end{array}$ & $\begin{array}{c}\text { P2 } \\
(n=47)\end{array}$ & $\begin{array}{c}\text { P3 } \\
(n=32)\end{array}$ & $\begin{array}{c}\text { P4 } \\
(n=47)\end{array}$ & \\
\hline BA-5 & - & - & 1 & 1 & 2 & - & - & - & - & - \\
\hline BA-21 & - & - & 4 & - & 4 & - & - & - & - & - \\
\hline BA-29 & 1 & - & 1 & - & 2 & - & - & - & - & - \\
\hline BA-61 & - & - & - & 1 & 1 & - & - & - & - & - \\
\hline BA- 80 & - & - & - & - & - & - & - & - & 1 & 1 \\
\hline BA-105 & - & - & - & - & - & - & - & - & 1 & 1 \\
\hline BB-1 & - & - & 1 & - & 1 & - & - & - & - & - \\
\hline BB-5 & - & - & 2 & 1 & 3 & - & - & - & - & - \\
\hline BB-8 & - & - & - & 1 & 1 & - & - & - & - & - \\
\hline BB-9 & 4 & 2 & 1 & 1 & 8 & - & - & - & - & - \\
\hline BB-10 & - & 1 & - & - & 1 & - & - & - & - & - \\
\hline BB-12 & - & 2 & - & - & 2 & - & - & - & - & - \\
\hline BB-13 & - & 2 & - & - & 2 & - & - & - & - & - \\
\hline BB-14 & 3 & 1 & - & - & 4 & - & - & - & - & - \\
\hline BB-15 & - & 1 & - & - & 1 & - & - & - & - & - \\
\hline BB-16 & - & 4 & - & - & 4 & - & - & - & - & - \\
\hline BB-17 & - & - & 1 & 1 & 2 & - & - & - & - & - \\
\hline BB-21 & - & 1 & 25 & - & 26 & - & - & - & - & - \\
\hline BB-23 & - & - & 3 & 1 & 4 & - & - & - & - & - \\
\hline BB-24 & 2 & - & - & - & 2 & - & - & - & - & - \\
\hline BB-29 & 3 & - & 2 & 3 & 8 & - & - & - & - & - \\
\hline BB-30 & 2 & - & - & - & 2 & - & - & - & - & - \\
\hline BB-31 & - & 1 & 1 & 3 & 5 & - & - & - & - & - \\
\hline BB-39 & 1 & - & - & - & 1 & - & - & - & - & - \\
\hline BB-41 & - & - & 1 & - & 1 & - & - & - & - & - \\
\hline BB-45 & - & 1 & - & - & 1 & - & - & - & - & - \\
\hline BB-47 & 1 & - & - & - & 1 & - & - & - & - & - \\
\hline BB-48 & 2 & - & - & - & 2 & 1 & 1 & 1 & 1 & 4 \\
\hline BB-55 & - & - & 1 & - & 1 & - & - & - & - & - \\
\hline BB-56 & 1 & - & - & - & 1 & - & - & - & - & - \\
\hline BB-60 & - & 1 & - & - & 1 & - & - & - & - & - \\
\hline BB-61 & 1 & - & - & - & 1 & - & - & - & - & - \\
\hline BB-62 & 1 & - & - & 1 & 2 & - & - & - & - & - \\
\hline BB-64 & 3 & - & - & 1 & 4 & - & - & - & - & - \\
\hline BC-2 & - & - & - & 1 & 1 & - & - & - & - & - \\
\hline BC- 8 & - & - & - & - & - & - & - & 1 & 3 & 4 \\
\hline BC-13 & - & 1 & 1 & - & 2 & - & - & - & - & \\
\hline BC-14 & - & - & - & 1 & 1 & - & - & - & - & \\
\hline BC-16 & - & 1 & - & 3 & 4 & 2 & - & - & - & 2 \\
\hline BC-24 & 2 & - & - & - & 2 & - & - & - & - & - \\
\hline BC- 25 & - & 1 & - & - & 1 & - & - & - & - & - \\
\hline BC-26 & 1 & - & - & - & 1 & - & - & - & - & - \\
\hline BC-31 & - & 1 & - & - & 1 & - & - & - & - & - \\
\hline BC-32 & 1 & - & - & 4 & 5 & - & - & - & - & - \\
\hline BD-2 & 1 & - & - & - & 1 & - & - & 1 & 1 & 2 \\
\hline BD-4 & - & - & - & - & - & 1 & - & - & - & 1 \\
\hline BD-5 & - & - & - & - & - & - & 1 & - & - & 1 \\
\hline BD-6 & - & - & - & - & - & 1 & - & - & - & 1 \\
\hline BD-8 & - & - & - & - & - & 3 & 1 & 1 & 1 & 6 \\
\hline BD-9 & - & 1 & - & - & 1 & - & - & - & - & - \\
\hline BD-11 & 1 & - & - & - & 1 & - & - & - & - & - \\
\hline BD-12 & - & 1 & - & - & 1 & - & - & 1 & 1 & 2 \\
\hline BD-13 & - & - & - & - & & 1 & 1 & 2 & 3 & 7 \\
\hline BD-14 & 1 & - & - & - & 1 & - & 1 & 3 & 3 & 7 \\
\hline BD-16 & - & - & - & - & & 38 & 39 & 22 & 32 & 131 \\
\hline BF-4 & - & 1 & - & - & 1 & - & - & - & - & - \\
\hline BG-1 & - & 2 & - & 2 & 4 & - & - & - & - & - \\
\hline BG-2 & 1 & - & - & - & 1 & - & - & - & - & - \\
\hline BH-1 & - & 1 & - & 1 & 2 & - & - & - & - & - \\
\hline BI-1 & - & 2 & - & 1 & 3 & - & - & - & - & - \\
\hline $\begin{array}{l}\text { Total number of } \\
\text { pathotypes per field } \\
\text { and grand total of } \\
\text { isolates }\end{array}$ & 21 & 21 & 14 & 18 & 136 & 7 & 6 & 8 & 11 & 170 \\
\hline
\end{tabular}

Thirty pathotypes were identified based on reaction type on eight international differential cultivars in eight fields of 'Primavera' and 'Bonança' rice during the 2-year period of this survey (Table 3). Of 170 test isolates of $M$. grisea collected from 'Primavera' three pathotypes, IF-
1, ID-9 and IC-9 were found to be predominant among the 22 pathotypes identified. The pathotypes IB-41 and IB-9 occurred at a higher frequency among the 20 other pathotypes identified in tests conducted with 136 isolates collected from four fields of 'Bonança'. Prabhu et al (2002b) 
Estimation of phenotypic diversity in field populations of Magnaporthe grisea...

TABLE 3 - International pathotypes and their frequency in eight different upland rice fields

\begin{tabular}{|c|c|c|c|c|c|c|c|c|c|c|}
\hline \multirow[b]{2}{*}{$\begin{array}{l}\text { International } \\
\text { pathotypes }{ }^{1}\end{array}$} & \multicolumn{4}{|c|}{ Rice field $^{2}$} & \multirow{2}{*}{$\begin{array}{c}\text { Total } \\
\text { number } \\
\text { of } \\
\text { isolates } 4\end{array}$} & \multicolumn{4}{|c|}{ Rice field $^{3}$} & \multirow{2}{*}{$\begin{array}{c}\text { Total } \\
\text { number of } \\
\text { isolates } 4\end{array}$} \\
\hline & $\begin{array}{c}\text { B1 } \\
(n=34)\end{array}$ & $\begin{array}{c}\text { B2 } \\
(n=29)\end{array}$ & $\begin{array}{c}\text { B3 } \\
(n=45)\end{array}$ & $\begin{array}{c}\text { B4 } \\
(n=28)\end{array}$ & & $\begin{array}{c}P 1 \\
(n=47)\end{array}$ & $\begin{array}{c}P 2 \\
(n=44)\end{array}$ & $\begin{array}{c}P 3 \\
(n=47)\end{array}$ & $\begin{array}{c}P 4 \\
(n=32)\end{array}$ & \\
\hline IA-1 & - & - & - & 2 & 2 & - & - & - & - & - \\
\hline IA-41 & 1 & - & - & - & 1 & - & - & - & - & - \\
\hline IB-1 & - & - & 2 & 2 & 4 & - & 1 & 5 & 4 & 10 \\
\hline IB-9 & 6 & 4 & 24 & 6 & 40 & 1 & 1 & - & - & 2 \\
\hline IB-13 & - & - & 3 & 1 & 4 & - & - & - & - & - \\
\hline IB-17 & - & - & - & - & - & - & - & 4 & 3 & 7 \\
\hline IB-21 & - & - & - & - & - & - & - & 1 & 1 & 2 \\
\hline IB-25 & - & - & - & - & - & - & 1 & 1 & - & 2 \\
\hline IB-33 & 1 & 2 & 1 & 2 & 6 & - & - & 1 & - & 1 \\
\hline IB-37 & 1 & - & - & - & 1 & - & - & - & - & - \\
\hline IB-41 & 16 & 20 & 12 & 7 & 55 & 1 & 2 & - & - & 3 \\
\hline IB-45 & 4 & 1 & 3 & 2 & 10 & - & - & - & - & - \\
\hline IB-49 & - & - & - & 1 & 1 & 1 & - & 5 & 5 & 11 \\
\hline IB-57 & 1 & - & - & - & 1 & - & 3 & 3 & 2 & 8 \\
\hline IB-58 & 1 & - & - & - & 1 & - & - & - & - & - \\
\hline IB-61 & 2 & - & - & 1 & 3 & - & - & - & - & - \\
\hline IB-63 & 1 & - & - & - & 1 & - & - & - & - & - \\
\hline IC-1 & - & - & - & 1 & 1 & 3 & - & 2 & 1 & 6 \\
\hline IC -9 & - & 1 & - & - & 1 & 10 & 4 & 2 & - & 16 \\
\hline IC-17 & - & 1 & - & - & 1 & - & - & 1 & 1 & 2 \\
\hline IC -25 & - & - & - & - & - & 3 & 4 & 2 & 2 & 11 \\
\hline IC-26 & - & - & - & - & - & - & - & 1 & - & 1 \\
\hline ID-1 & - & - & - & - & - & 1 & 2 & 1 & 1 & 5 \\
\hline ID-9 & - & - & - & - & - & 16 & 12 & - & - & 28 \\
\hline ID-10 & - & - & - & - & - & - & 1 & - & - & 1 \\
\hline IE-1 & - & - & - & 1 & 1 & - & - & 2 & 2 & 4 \\
\hline IF-1 & - & - & - & 1 & 1 & 10 & 11 & 12 & 9 & 42 \\
\hline IG-1 & - & - & - & 1 & 1 & 1 & - & - & 1 & 2 \\
\hline IG-2 & - & - & - & - & - & - & 2 & 3 & - & 5 \\
\hline IH-1 & - & - & - & - & - & - & - & 1 & - & 1 \\
\hline $\begin{array}{l}\text { Total number of } \\
\text { pathotypes per field } \\
\text { and grand total of } \\
\text { isolates }\end{array}$ & 10 & 6 & 6 & 12 & 136 & 10 & 12 & 17 & 12 & 170 \\
\hline
\end{tabular}

${ }^{1}$ International pathotypes were identified based on eight standard international rice differentials. ${ }^{2} \mathrm{~B}=$ 'Bonança', ${ }^{3} \mathrm{P}=$ 'Primavera', the numbers followed by the letters B and P refer to the field number. ${ }^{4}$ Total number of pathotypes were based on samples collected and tested from eight fields including two rice cultivars and two years.

identified two pathotypes in five isolates collected from 'Bonança' in experimental fields; four of them were IB-9 and one was IB-33. In the present study, IB-33 was detected at low frequency in commercial fields of the cultivar 'BRS Bonança', while 55 of the 58 isolates were identified as pathotype IB-41. The composition of pathotypes in the experimental plots and commercial fields is different even though both virulent and avirulent pathotypes do preexist under natural field conditions.

The diversity in pathotypes ranged from 6 to 21 based on reaction type on Brazilian differentials and 6 to 17 using international differentials (Tables 2 and 3). Fields 1, 2 and 4 of 'Bonança' showed a high pathotype diversity using Brazilian differentials (Table 2). Isolates that have been classified as the same pathotype using international set of differentials could be further differentiated from Brazilian differentials. This indicates that the former could not fully discriminate virulences in local $M$. grisea populations. The information on pathotype diversity determined using the Brazilian differentials has more applied value in improving rice cultivars for blast resistance than with the international differentials (Prabhu et al., 2002b).

The 'Primavera' and 'Bonança' M. grisea populations in eight commercial fields, as measured by Simpson, Shannon and Gleason indices, showed similar phenotypic diversities (Figures 1 and 2). Considering the standard reaction on eight Brazilian differential cultivars, the index values ranged from 0.22 to 0.97 for Simpson, 0.55 to 2.94 for Shannon 

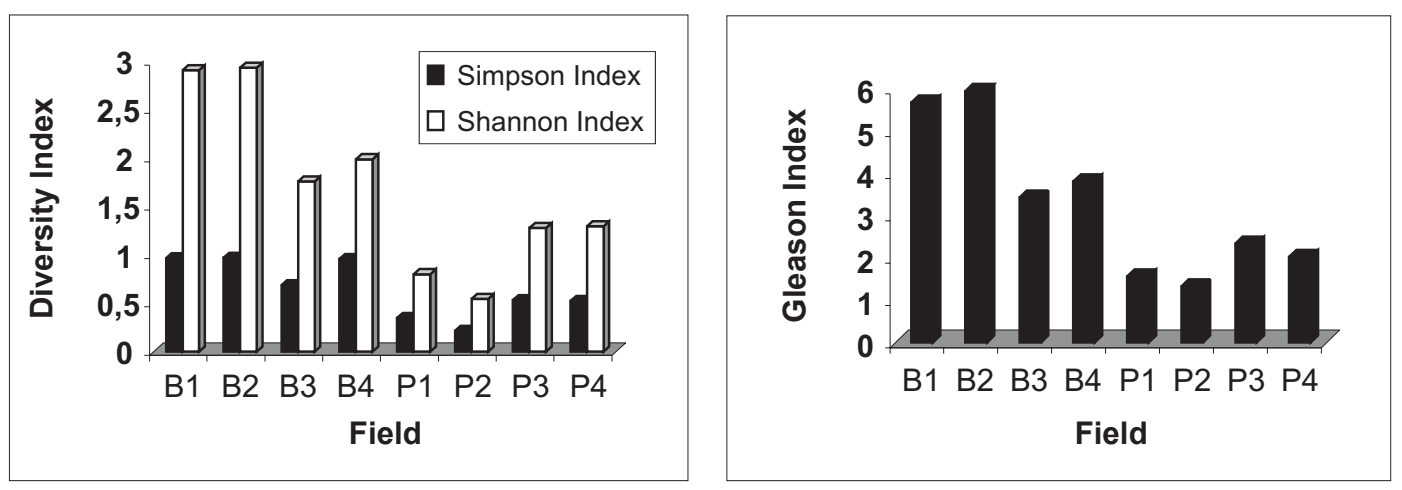

FIG. 1 - Phenotypic diversity indexes of Pyricularia grisea populations from commercial fields of upland rice cultivars Bonança (B1 and B2 = 2002; B3 and B4 = 2003) and Primavera (P1 and P2 = 2002; P3 and P4 = 2003) analyzed utilizing Brazilian race differential set. A = Simpson and Shannon indexes; B = Gleason index (2001-2003).
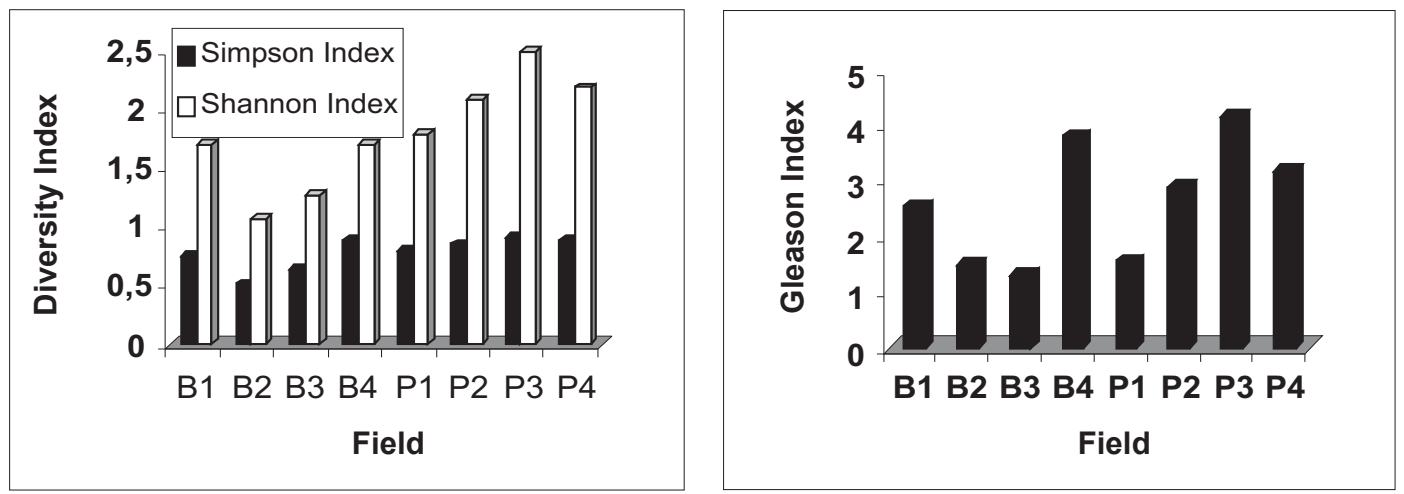

FIG. 2 - Phenotypic diversity indexes of Pyricularia grisea populations obtained from commercial fields of upland rice cultivars Bonança $(\mathrm{B} 1$ and $\mathrm{B} 2=2002$; B3 and B4 $=2003)$ and Primavera $(\mathrm{P} 1$ and P2 $=2002 ; \mathrm{P} 3$ and P4 = 2003) analyzed utilizing International race differential set. A = Simpson and Shannon indexes; $B=G l e a s o n$ index (2001-2003).

and 1.3 to 5.99 for Gleason index (Figure 1). However, the phenotypic diversity was lower in commercial rice fields of 'Primavera' than in the fields of 'Bonança', independent of the diversity index utilized, year and location (Figure 1). The fields $\mathrm{B} 1$ and $\mathrm{B} 2$ of 'Bonança' in the rice growing season of 2001/2002, and B4 in the succeeding year, exhibited high phenotypic diversity utilizing Brazilian differentials, whereas B1 (Figure 1), B2 and B3 showed relatively lower diversity utilizing international differentials (Figure 2). The two sets of differentials used in the present study differentiated phenotypic diversity in different ways in all of the eight subpopulations analyzed. This could be attributed to differences in resistance genes of the two differential sets. Similar results were observed in the wheat-Puccinia recondita $\mathrm{f}$. $\mathrm{sp}$. tritici pathosystem (Kolmer, 1991). Considering Brazilian differentials, the four subpopulations from 'Primavera' (P1, P2, P3 and P4 fields) did not show standard deviation, and only one phenotype dominated in the subpopulation. The standard deviation was observed only in subpopulations B1, B2 and B4 fields of 'Bonança' (Figure 1).
Virulence frequencies resistance to genes not deployed in the region, such as those present in the international differentials, are generally low when compared to virulence frequencies for the Brazilian differential cultivars. The contribution of pathotype number, sample size, and frequency distribution or evenness, and to each diversity index evaluated, was determined through the coefficients of determination in linear regression (Table 4). The Simpson index was more sensitive than those of Shannon and Gleason to pathotype number and standard deviation when Brazilian differentials were utilized. On the other hand, Gleason was a more sensitive index to standard deviation if international differentials were considered. The sample size did not significantly influence the diversity index. Kolmer (1991) conducted multiple regression analysis to determine the proportion of variation in the diversity indices that could be accounted for by the independent variables, such as sample size, number of pathotypes and evenness of pathotype frequencies. The Gleason index was found to be more sensitive to the number of 
Estimation of phenotypic diversity in field populations of Magnaporthe grisea...

TABLE 4 - Coefficients of determination $\left(\mathrm{R}^{2}\right)$ between parameters or components and three indexes of diversity applied to samples Magnaporthe grisea of rice collected from BRS Bonança and BRS Primavera

\begin{tabular}{lcccccc}
\hline \hline \multirow{2}{*}{\begin{tabular}{l} 
Index \\
\cline { 2 - 6 }
\end{tabular}} & \multicolumn{3}{c}{ Brazilian } \\
\cline { 2 - 6 } & $\begin{array}{c}\text { Sample } \\
\text { Size }\end{array}$ & $\begin{array}{c}\text { Pathotype } \\
\text { number }\end{array}$ & $\begin{array}{c}\text { Standard deviation of } \\
\text { frequency }\end{array}$ & $\begin{array}{c}\text { Sample } \\
\text { Size }\end{array}$ & $\begin{array}{c}\text { Pathotype } \\
\text { number }\end{array}$ & $\begin{array}{c}\text { Standard deviation of } \\
\text { frequency }\end{array}$ \\
\hline Gleason & 0,289 & 0,531 & 0,864 & 0,002 & 0,857 & 0,815 \\
Shannon & 0,047 & 0,617 & 0,864 & 0,064 & 0,842 & 0,636 \\
Simpson & 0,563 & 0,771 & 0,978 & 0,001 & 0,796 & 0,636 \\
\hline
\end{tabular}

pathotypes, whereas Shannon and Simpson indexes were more sensitive to the evenness of race frequencies in relation to phenotypic diversity of two subpopulations of $P$. recondita $\mathrm{f}$. sp. tritici. The phenotypic diversity of the two pathogen subpopulations from 'Primavera' and 'Bonança', as measured by the three indices of diversity, can be attributed to the directional selection in pathotype frequency determined by the host cultivar. The low phenotypic diversity of the pathogen subpopulations from 'Primavera' was maintained in both years independent of location. This could be attributed to the extensive areas planted with the cultivar and also to the fact that this cultivar was released earlier than 'Bonança'. Host selection seems to play a major role in structuring the pathogen populations (Chen et al., 1995).

The risk involved in resistance breakdown by the development of a compatible virulence phenotype in the population of $M$. grisea is greater in 'Bonança' than in 'Primavera' if it is improved for blast resistance by incorporating vertical genes through back cross breeding procedure. Thus, it may be advantageous and safer to breed 'Primavera' through this procedure as segregating populations could be screened for resistance against a pathogen population that has reached some degree of evenness.

\section{ACKNOWLEDGEMENTS}

We acknowledge with grateful thanks to Embrapa Arroz e Feijão for providing the laboratory and greenhouse facilities for conducting this research and to CAPES for awarding a research fellowship to the first author. Thanks are also due to Pedro Maurício Machado and Romilda Amaral Melo for assistance in the plant pathology laboratory whenever needed.

\section{REFERENCES}

ARAÚJO, L.G., PRABHU, A.S., OLIVEIRA, C.F. \& BERNI, R.F. Efeito da brusone nas panículas nos componentes de produtividade nas cultivares de arroz Primavera e Bonança. Summa Phytopathologica 30:265-270. 2004.
ATKINS, J.G., ROBERT, A.L., ADAAIR, C.R., GOTO, K., KOZAKA, T., YANAGIDA, R., YAMADA, M. \& MATSUMOTO, $\mathrm{S}$. An international set of rice varieties for differentiating races of Pyricularia oryzae. Phytopathology 57:297-301. 1967.

CHEN, D., ZEIGLER, R.S., LEUNG, H. \& NELSON, R.J. Population structure of Pyricularia grisea at two screening sites in the Philippines. Phytopathology 85:1011-1020. 1995.

CORNELIO, V.M.O. Identificação de raças de Pyricularia grisea Sacc. no arroz de terras altas em Minas Gerais, incidência e severidade da brusone e tipos de resistência. Tese de Doutorado. Lavras MG. Universidade Federal de Lavras. 2001.

CORREA-VICTORIA, F.J. \& ZEIGLER, R.S. Pathogenic variability in Pyricularia grisea at a rice blast "hot-spot" breeding site in Eastern Colombia. Plant Disease 77:1029-1035. 1993.

FILIPPI, M.C. \& PRABHU, A.S. Phenotypic virulence analysis of Pyricularia grisea isolates from Brazilian upland rice cultivars. Pesquisa Agropecuária Brasileira 36:27-35. 2001.

FILIPPI, M.C. \& PRABHU, A.S. Genetic diversity and virulence pattern in field populations of Pyricularia grisea from rice cultivar Metica-1. Pesquisa Agropecuária Brasileira 37:1681-1688. 2002.

GOODWIN, S.B. The population genetics of Phytophthora. Phytopathology 87:462-473. 1997.

GROTH, J.V. \& ROELFS, A.P. The concept and measurement of phenotypic diversity in Puccinia graminis on wheat. Phytopathology 77:1395-1399. 1987.

INTERNATIONAL RICE RESEARCH INSTITUTE. Standard evaluation system for rice. International rice testing program. $3^{\text {rd }}$ ed. Los Baños. International Rice Research Institute. 1988.

KOLMER, J.A. Phenotypic diversity in two populations of Puccinia recondita $\mathrm{f}$. sp. tritici in Canada during 1931-1987. Phytopathology 81:311-315. 1991.

KOSMAN, E. Difference and diversity of plant pathogen populations: a new approach for measuring. Phytopathology 86:1152-1156. 1996.

LEONARD, K.J., ROELFS, A.P. \& LONG, D.L. Diversity of virulence within and among populations of Puccinia recondite f. sp. tritici in different areas of the United States. Plant Disease 76:500-504. 1992.

LEVY, M., CORREA, F.J., ZEIGLER, R.S., XU, S. \& HAMER, J.E. Genetic diversity of the rice blast fungus in a disease nursery in Colombia. Phytopathology 83:1427-1433. 1993.

LING, K.C. \& OU, S.H. Standardization of the international race numbers of Pyricularia oryzae. Phytopathology 59:339-342. 1969. 
MALAVOLTA, V.M.A. \& SOUZA, T.M.W. Variabilidade de Pyricularia oryzae no Estado de São Paulo. Summa Phytopathologica 18:287-290. 1992.

OU, S.H. Pathogen variability and host resistance of the rice blast fungus, Pyricularia oryzae Cav. Annual Review of Phytopathology 18:167-187. 1980.

PIELOU, E.C. Ecological diversity. New York. John Wiley \& Sons. 1975.

PRABHU, A.S. \& FILIPPI, M.C. Graus de resistência a brusone e produtividade de cultivares melhoradas de arroz de terras altas. Pesquisa Agropecuária Brasileira 36:1453-1459. 2001.

PRABHU, A.S., CASTRO, E.M., ARAÚJO, L.G. \& BERNI, R.F. Resistance spectra of six elite breeding lines of upland rice to Pyricularia grisea. Pesquisa Agropecuária Brasileira 38:203-210. 2003.

PRABHU, A.S., OLIVEIRA, C.F., ARAÚJO, L.G. \& BERNI, R.F. Determinação de danos potenciais em produtividade causada por brusone em arroz de terras altas. Fitopatologia Brasileira. 27:152. 2002a.

PRABHU, A.S., FILIPPI, M.C. \& ARAÚJO, L.G. Pathotype diversity of Pyricularia grisea from improved upland rice cultivars in experimental plots. Fitopatologia Brasileira 27:468-473. $2002 \mathrm{~b}$.

PRABHU, A.S., FILIPPI, M.C., ARAÚJO, L.G. \& FARIA, J.C. Genetic and phenotypic characterization of isolates of Pyricularia grisea from rice cultivar Epagri 108 and Epagri 109 in State of Tocantins. Fitopatologia Brasileira 27:566-573. 2002c.

XIA, J.Q., CORRELL, J.C., LEE, F.N., ROSS, W.J. \& RHOADS, D.D. Regional population diversity of Pyricularia grisea in Arkansas and the influence of host selection. Plant Disease 84:877884. 2000.

ZEIGLER, R.S., CUOC, L.X., SCOTT, R.P., BERNARDO, M.A., CHEN, D.H., VALENT, B. \& NELSON, R.J. The relationship between lineage and virulence in Pyricularia grisea in the Philippines. Phytopathology 85:443-451. 1995. 